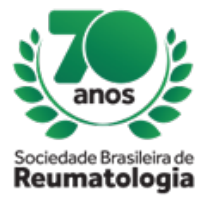

\title{
INFLAMMATORY AORTIC ANEURYSM SECUNDARY TO GIANT CELL ARTERITIS
}

Gabriel Ribeiro Leão Barroso (UFMT, Sinop, MT, Brasil), Allana Campos Alves (UFMT, Sinop, MT, Brasil), Diogo Rios de Avila (UFMT, Sinop, MT, Brasil), Andressa Gabrielly Rodrigues Beserra (UFMT, Sinop, MT, Brasil), Gabriel Freitas de Campos (UFMT, Sinop, MT, Brasil), Fabiana de Castro Machado (UFMT, Sinop, MT, Brasil), Heloisa Maria Lopes Scarinci (UFMT, Sinop, MT, Brasil), Flavio Fernandes Barboza (UFMT, Sinop, MT, Brasil)

\section{BACKGROUND}

Giant cell arteritis (GCA) is the most common systemic vasculitis in Western countries. It mainly affects individuals older than 50 years, basically involves vessels of great caliber, and has an incidence rate of about 200 cases per 100,000 inhabitants, with women affected 2-6 times more than men. GCA has great clinical relevance, and its main and most common complication is the large-vessel stenosis, rarely presenting aneurysmal lesions.

\section{CASE REPORT}

A 65-year-old woman complained of daily night fever, temporal headache, jaw claudication, weight loss $(3 \mathrm{~kg})$, and night sweats for approximately 60 days. She also presented intense pain in the scapular and pelvic girdles.

The patient had multiple negative blood cultures and underwent empiric antibiotic therapy for one month, showing no improvement.

Initial tests showed hemoglobin $(\mathrm{Hb})$ of $9.8 \mathrm{~g} / \mathrm{dL}$, erythrocyte sedimentation rate (ESR) of $110 \mathrm{~mm} / \mathrm{hr}, \mathrm{C}$ reactive protein (CRP) of $26 \mathrm{mg} / \mathrm{L}$, normal liver enzymes and renal function tests.

Aortic arch CT angiography revealed an ulcerated and inflamed aneurysm lesion (figure 1 and 2). Abdominal CT showed no abnormalities.

Doppler ultrasound of carotid arteries showed bilateral slight thickening of the common carotid artery, with no evidence of active inflammation.

After excluding the most common neoplastic causes, the diagnosis of GCA was assumed.

We started treatment with prednisone $1 \mathrm{mg} / \mathrm{kg}$, yielding response in 24 hours, with improvement of the general condition, anemia, fever, headache, and body aches. ESR examination showed improvement, with return to baseline levels.

A weekly dose of $15 \mathrm{mg}$ methotrexate was added to the treatment, with subsequent increase to $25 \mathrm{mg}$ because of fever relapse and increase in ESR whenever doses of prednisone were reduced.

After six months of follow-up and treatment, new CT angiography showed doubling of aortic aneurysm size, with imminent rupture, lesion without active inflammatory activity, normal ESR, and absence of anemia.

The patient, in joint follow-up with a cardiologist, presented emergency surgical indication and was referred to the cardiovascular surgery team.

\section{CONCLUSION}

Although aneurysmal lesions are not frequent in cases of GCA, being classified as rare, these injuries and their inflammatory nature should be part of the clinical suspicion, especially when differential diagnoses such as syphilis and tuberculosis are excluded. 